\title{
Escritos, Imagens e Artefatos: ou a Viagem de Thevet à França Antártica
}

Ronald José RAMINELLI*

Resumo: Por meio de escritos, imagens e artefatos, frei André Thevet, cosmógrafo do rei da França, recriava plantas, animais, povos e geografia do Novo Mundo. Os recursos gráficos e as coleções permitiam-no mobilizar informações, comprovar seus registros escritos e, por certo, disponibilizar esses dados ao rei, nobres e demais curiosos. Os avanços da imprensa tornaram possível o conhecimento sobre mundos distantes, saber que atingia, cada vez mais, um público mais vasto, enquanto as coleções permaneceram restritas ao circuito aristocrático. Pretende-se, portanto, investigar os "elementos americanos" escolhidos e recolhidos por Thevet para testemunhar sua viagem e torná-la presente, ou representada, para seus contemporâneos.

Palavras-Chave: França Antártica; Colonização Francesa; André Thevet.

Em 18 de dezembro de 1556, o rei Henrique concedeu o privilégio real para publicação da obra Les singularitez de la France Antarctique ${ }^{1}$ do frei André Thevet, natural de Angoulême. Tratava-se da narrativa de sua viagem à América e às outras terras e ilhas descobertas, quando atuou na qualidade de "aumônier" do cavaleiro de Malta, Nicolas Durand de Villegagnon. Com enorme sacrifício e labor, o frei redigiu as singularidades de todas essas regiões para o contentamento e proveito das pessoas estudiosas do reino da França e para ilustração e enriquecimento das boas letras. Não permaneceu

* Departamento de História - Instituto de Ciências Humanas e Filosofia - UFF - 24210-380 - Niterói - RJ - Brasil. E-mail: rraminelli@uol.com.br 
muito tempo na França Antártica, pois ficou doente e teve de ser repatriado depois de 10 semanas $^{2}$. A brevíssima estada não o impediu de escrever sobre vários aspectos da natureza e dos povos americanos. Ao retornar à pátria, recebeu o real privilégio que tornava ilegal qualquer divulgação da obra sem a permissão e o consentimento da livraria ou impressora indicada para publicação. O soberano proibia a todas as outras, a todos os súditos em geral, que imprimissem, ou que fizessem imprimir, ou que vendessem ou distribuíssem o dito livro até o prazo de dez anos após a sua primeira impressão. Com a graça do rei, estava assim assegurado aos herdeiros do senhor De La Porte o direito de publicação e venda do livro.

$\mathrm{Na}$ carta de privilégio, ficava também estabelecido, de forma difusa, que os ensinamentos do frei seriam úteis aos homens estudiosos do reino da França e para promover o melhoramento das belas letras. No prefácio, Thevet ainda concedeu outras pistas sobre o público leitor, alvo de seus esforços, e sobre os objetivos que o levaram a redigir suas memórias da viagem. Os fatos e a fiel observação das diversas terras e nações, juntamente com os seus costumes e modos de vida, contribuíam, segundo o frei, para aumentar a perfeição do homem. Essas atividades, por certo, eram as mais louváveis entre todas, pois só elas de fato permitiriam o enriquecimento do espírito com heróica virtude e sólida ciência. $O$ frei não enfatizou, porém, como as preciosas informações inventariadas viabilizariam a sustentação da nova conquista francesa, ele nem mesmo concebia as potencialidades da França Antártica como riquezas coloniais. Seus interesses, por certo, eram outros ${ }^{3}$.

Para não ser considerado, qual Diógenes entre os atenienses, como pessoa ociosa e inútil, Thevet decidiu registrar por escrito as inúmeras e notáveis coisas que diligentemente observou durante a viagem. Para tanto, concedeu a localização e a situação dos lugares, definiu o clima, a zona e o paralelo. Descreveu os mares, as ilhas e a terra firme, a temperatura do ar, os costumes e os modos de vida de seus habitantes. Não descuidou dos aspectos e características dos animais aquáticos e terrestres, das árvores, arbustos e seus respectivos frutos, dos 
minerais e das pedras preciosas. Seus escritos eram acompanhados de imagens que atuavam como testemunhos visuais das experiências. Assim, segundo o frei, ele representou visualmente, com a máxima fidelidade, os mais diversos aspectos da jornada. Essa viagem seria ainda representada por meio de artefatos recolhidos entre as comunidades locais. Para comprovar suas observações escritas e reforçar a veracidade de suas ilustrações, ele recolheu, entre as comunidades, artefatos para compor uma coleção. Para além de validar o discurso, as raridades americanas destinavam-se a alimentar um sistema de patronagem ${ }^{4}$, seriam dons ofertados a seus superiores. Os artefatos, portanto, viabilizariam doações de peças raras e exóticas aos senhores de prestígio. Como recompensa de seus serviços e da oferenda, Thevet talvez almejasse o lugar de cosmógrafo do rei.

Composto de penas vermelhas, o manto tupinambá serviu tanto para assegurar a seus escritos mais autenticidade, quanto para prestar vassalagem à casa do Cardeal Sens, como no trecho a seguir:

"Quem quiser poderá ver um desses mantos, pois fiz presente de um deles ao Senhor de Troistieux, fidalgo da casa do Reverendíssimo Monsenhor Cardeal de Sens, Guarda dos Selos de França, grande apreciador de todas as singularidades e admirador das pessoas virtuosas" 5 .

Enfim, os artefatos cumpriam essa dupla função, eram prova material de seus escritos e fonte de prestígio ao serem doados a um poderoso senhor. Os artefatos e demais testemunhos materiais da viagem formavam uma coleção, talvez um pequeno gabinete de curiosidades ${ }^{6}$. Entre as preciosidades, o frei coletou na América um instrumento confeccionado a partir de um fruto, semelhante a uma abóbora, de onde os americanos tiravam a polpa, enchiam-no de grãos de milho e sementes e, por fim, enfeitavam-no com belas plumagens. Guardados em cada cabana, esses objetos eram misteriosos e motivo de reverência por parte de todos os índios. Esses pobres idólatras, comentou Thevet, entendiam que era o próprio Tupã quem lhes falava 
quando o instrumento soava. O chocalho revelava a seus profetas tudo o que eles queriam saber, pois consideravam que esse artefato tinha força divinatória. Não adoravam imagens, nem estátuas, nenhuma coisa concreta senão este instrumento que soava quando chocalhado. $O$ frei narrou que teve de surrupiar este artefato dos índios para levá-lo ao Velho Mundo. Com esse chocalho e numerosas plumas, ele presenteou ao Senhor de Nicolas de Nicolai, geógrafo do rei, pessoa de grande competência, amante e colecionador de antigüidades e objetos curiosos. Esse senhor mostrou estes presentes ao Rei quando Sua Majestade, estando em Paris, foi visitá-lo em sua casa para ver o livro a respeito do Levante que o Senhor de Nicolai mandara imprimir. Esses objetos causaram enorme prazer à Sua Majestade, sobretudo devido à sua novidade, pois até então eram completamente desconhecidos ${ }^{7}$. O próprio rei seria também presenteado com artefato adornado com penas amarelas de tucano: trouxe para França, escreveu André Thevet, "un chapeau fait de ce plumage, sort beau \& riche, lequel a éste presenté au Roy, comme chose singuliere"

Thevet recorreu aos testemunhos escritos, visuais e materiais para promover ainda uma verdadeira querela contra os antigos e os modernos. Recorreu à tradição clássica e a seus contemporâneos para demonstrar o quanto a experiência era capaz de contestar escritos e imagens que circulavam entre os estudiosos. Assim, não se poderia acreditar que os homens das novas terras eram tão disformes como garantiam algumas autoridades que pareciam estar dormindo, ou mesmo sonhando, quanto descreveram "indivíduos com orelhas pendentes até a altura do calcanhar, ou então com apenas um olho no meio da testa (...), outros sem cabeça, e ainda outros que só teriam um pé, porém tão descomunal que podiam com ele cobrir-se do ardor do sol..." ${ }^{\prime \prime}$. Esses equívocos difundiam-se e enganavam os leitores por ser respaldados na tradição ${ }^{10}$. Os antigos cosmógrafos jamais tiveram conhecimento da América, jamais registraram informações nesse sentido. Eles não teriam dúvidas de divulgar o novo continente, caso soubessem da sua existência e de sua vastíssima extensão. As novas terras seriam logo denominadas 
de quarta parte do mundo, "car elle est beaucoup plus grande que nulle des autres"11. Os antigos deveriam, no entanto, ser perdoados por suas fantasias. Os erros resultavam da falta de crítica aos testemunhos, pois baseavam suas afirmações mais em conjecturas do que na experiência: “...yans parlé $p$ conjectures, \& nõ par experience"12.

Nesse sentido, André Thevet ainda assegurava a seus leitores que os selvagens não viviam nos campos e florestas como animais e nem tinham seus corpos recobertos de pêlos, como ursos, cervos ou leões. Esses testemunhos não advinham da observação pessoal, já que eles jamais se depararam com um selvagem. Eles, por certo, repetiam a antiga crença, uma mera opinião geral. O frei, porém, não promovia a sobrevida dessas histórias, pois podia afirmar seguramente que a aparência dos nativos era exatamente o oposto. Os selvagens americanos depilavam todo o corpo, incluindo a barba e os pêlos pubianos. Seus escritos e ilustrações comprovavam a existência de homens com corpos lisos e bem cuidados. Portanto, seu leitor não deveria levar-se, doravante, pela opinião geral, nem acreditar na aparência que os pintores emprestavam aos selvagens, pois a estes artistas era permitido representar as coisas do jeito que achassem melhor. Assim como era permitido aos poetas, aos artistas era também concedida a licença para dar asas à imaginação criadora ${ }^{13}$. Suas imagens, portanto, nem sempre retratavam com fidelidade as singularidades da América.

"As singularidades da França Antártica" receberam inúmeras ilustrações do gravador Jean Cousin, e outros desconhecidos, que abordavam três temas básicos: os costumes americanos, os animais e as plantas, conforme proposta explicitada no prefácio aos leitores. Os escritos e as imagens traduziam a longa experiência e a fiel observação das diversas terras e nações, além de contribuir para aumentar a perfeição do homem. Baseados em sólida ciência, os escritos de Thevet eram matérias destinadas instruir e enriquecer os espíritos. Recorrendo a cerca de 20 imagens, o frei pretendeu consolidar o seu testemunho, rebater as falsas opiniões e indicar, enfim, as singularidades da França Antártica, sem desconsiderar o quanto 
os povos, os animais e as plantas eram diferentes das conhecidas no Velho Mundo. Inicialmente, tratou da natureza, dos peixes em particular e, depois de descrevê-los, procurou fornecer novas informações por meio das gravuras.

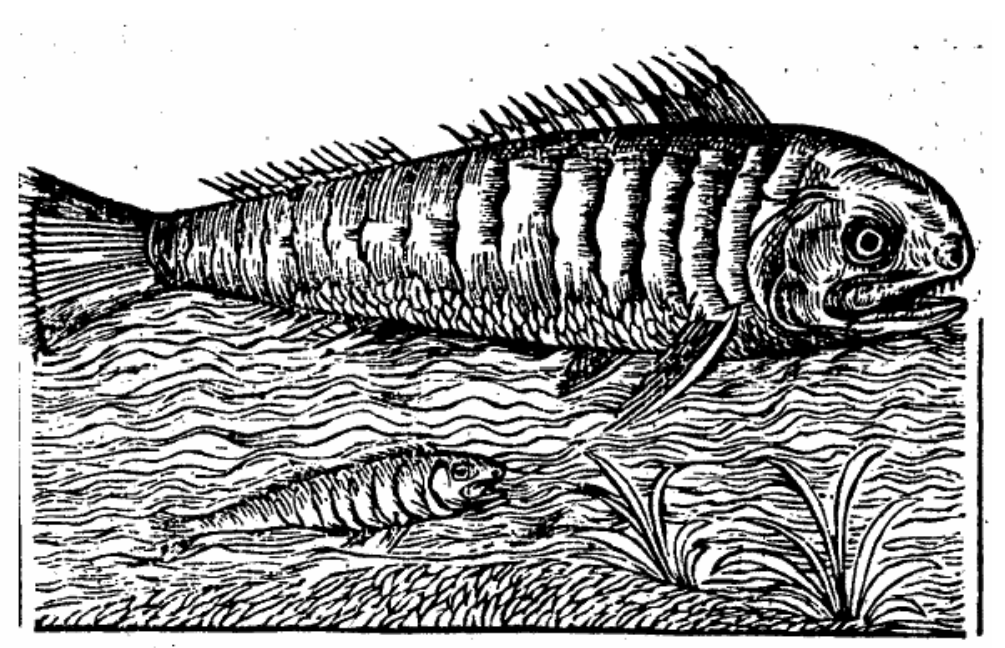

Sobre o peixe denominado de tamuatá (fig. 01), ele forneceu as seguintes informações:

"Consta deste volume sua gravura, sendo ele de fato tal e qual nela o representamos. Seu comprimento e seu volume são pouco menores que os nossos arenques. É revestido de placas, desde a cabeça até a cauda, assim como um pequeno animal terrestre que os selvagens chamam de tatu. Tem a cabeça de um peixe bom de se comer, ou pelo menos é isto o que pensam os selvagens, que o chamam em sua língua de tamuatá". ${ }^{14}$ 


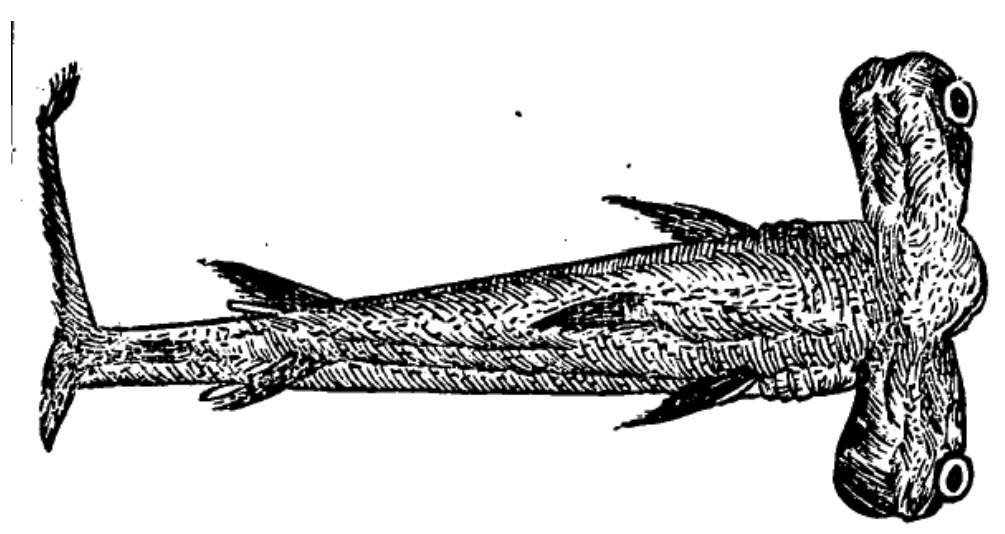

Também registrado em gravura, o peixe monstruoso, denominado de panapaná (fig. 02), tinha fendas laterais estreitas como as lampreias. A forma da cabeça era como se vê na gravura, descreveu Thevet. Os olhos ficam quase nas extremidades da cabeça, a um pé e meio de distância um do outro. Era um peixe bastante raro, mas a carne não era das melhores, pois lembrava a carne de cação ${ }^{15}$. Ao traduzir ao leitor como eram os peixes exóticos da América, frei Thevet recorreu a vários recursos. Além da imagem, descreveu-os por meio de medidas, "à distance d'un pied \& demi", e pelas estruturas anatômicas de peixes conhecidos na Europa, como o arenque, lampreia e cação. Resultavam assim espécies certamente monstruosas, pois eram compostos de partes e formas semelhantes encontradas na natureza. Quanto mais estranha a espécie, mais André Thevet recorria aos testemunhos e às comparações capazes de convencer os leitores da pureza e veracidade de suas descrições. 


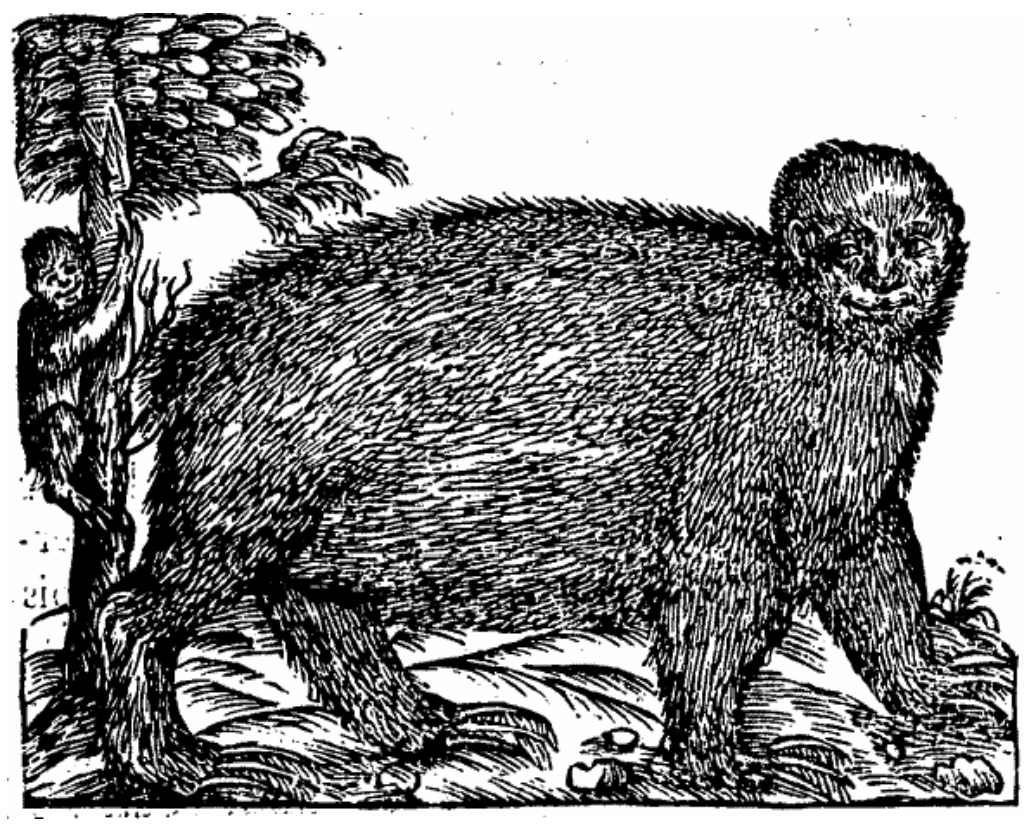

Em busca da fidelidade e da melhor tradução dos fatos, ele recorreu a toda forma de recursos para descrever a preguiça, o estranhíssimo animal por ele denominado de Haüt ou Haüthi (fig. 03). Segundo Thevet, era o bicho mais disforme que se podia imaginar, verdadeiro monstro que, de alguma forma, se assemelhava ao mono africano, urso, carpa e a uma criança. Quem nunca o viu, escreveu o frei, certamente considerará esta descrição inacreditável:

"É do tamanho de um mono africano adulto, apresentando uma barriga tão grande que chega quase a se arrastar no chão. A cabeça lembra a de uma criança, assim como também a cara, conforme pode ser visto na gravura tirada ao natural. Quanto preso, fica suspirando como uma criança que sente dores. Sua pele é cinzenta e felpuda como a de um ursinho. Tem patas compridas, cada uma com quatro dedos, três dos quais com 
unhas parecendo grandes espinhas de carpa, com as quais trepa nas árvores onde fica por mais tempo do que em terra. Quase não tem pêlos na cauda, que mede três dedos de comprimento. Outra coisa notável é que pessoa alguma jamais viu este bicho se alimentando, nem mesmo os selvagens que já ficaram espreitando debalde por longo espaço de tempo, querendo saber o que ele comeria...". ${ }^{16}$

Para finalizar, ele acrescenta que foram os próprios americanos que lhe contaram tal curiosidade.

Apesar de Aristóteles e os demais sábios antigos se esforçarem para desvendar a natureza dos animais, árvores e ervas, Thevet considerava os testemunhos antigos insuficientes para entender as singularidades americanas. Os escritos antigos, porém, traziam aos estudiosos proveito e deleite. Para confrontá-los, para enfrentar as autoridades cultuadas desde a antigüidade, o frei deveria se precaver com alguns recursos. Em princípio, avisava o leitor sobre a raridade e a singularidade das espécies da França Antártica e rogava para que essa apresentação não fosse mal interpretada. Para além do alerta, recorria a todo tipo de comparação e testemunhos. Não bastava a reprodução escrita de suas experiências, nem mesmo o recurso visual era definitivo para traduzir as singularidades. À escrita e à imagem somavam-se os testemunhos materiais, como a comparação com animais conhecidos e até com seres humanos, além dos sistemas de medida adotados na Europa. Por fim, ainda destacou que as informações sobre a preguiça originavam dos selvagens, ou melhor, ele dispunha também da observação atenta dos americanos que, certamente, achavam curioso o mencionado animal. Em busca de fidelidade, Thevet não poupou testemunhos, pois quanto mais singular era a espécie ou o evento, mais era necessário comprovar suas afirmativas.

As imagens também ilustravam os costumes americanos, especialmente as cenas de guerra e de canibalismo. Nas guerras, os selvagens demonstravam muita coragem e obstinação. Antes das pelejas corpo-a-corpo, mantinham entre eles uma certa distância para trocarem, de longe, injúrias e 
ameaças verbais. Faziam uns contra os outros medonhas e cruéis caretas, gritavam, gesticulavam com os braços e as mãos para exibir suas clavas e tacapes, conforme demonstrou a gravura escolhida por Thevet para ilustrar o evento (fig.04) ${ }^{17}$.

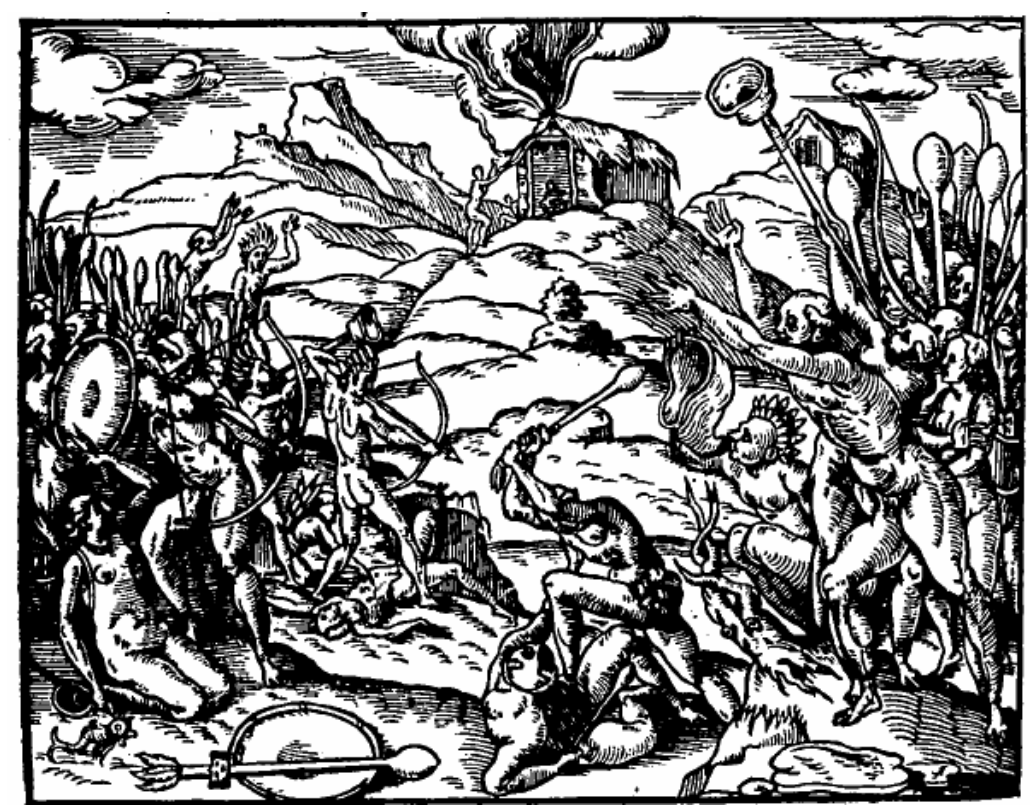

Mas não foram os recursos visuais o único meio encontrado pelo frei para demonstrar o quanto eram plausíveis e verossimilhantes tais práticas. Os exemplos oriundos dos textos clássicos concediam autoridade e erudição aos escritos do religioso. Assim, quando ameaçavam os inimigos com gritos e gestos, os selvagens pareciam imitar a antiga tática dos guerreiros romanos, que antes da luta gritavam de maneira terrível, proferindo medonhas ameaças. Este modo de agir foi posteriormente utilizado pelos gauleses em seus combates, conforme nos contou Tito Lívio. ${ }^{18}$ Entre os selvagens, quando 
falecia um chefe de família, suas esposas, parentes mais próximos e amigos guardavam pesadíssimo luto durante quatro ou cinco meses. Choravam os homens e mulheres, ficavam parados, deitados na rede ou sentados no chão. Nesse momento, abraçavam uns aos outros, como se pode ver na gravura ${ }^{19}$.

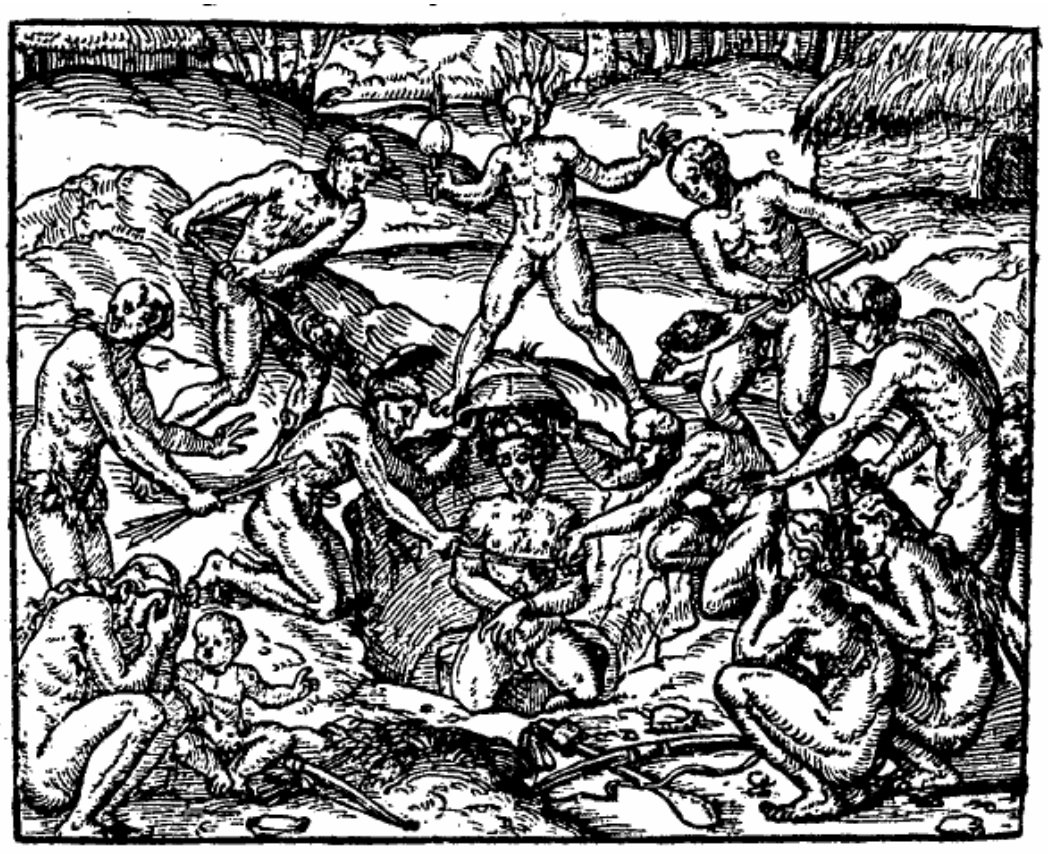

Depois de um mês do falecimento, os filhos do morto convidavam os amigos para uma festa em honra do pai. $\mathrm{Na}$ solenidade, apresentavam os corpos pintados e ornados de penas e executavam mil rituais e cerimônia. Essa tradição não era tão estranha aos antigos, pois certos habitantes da Grécia realizavam torneios fúnebres em memória do feroz leão derrotado por Hércules. Alexandre, o Grande, depois de visitar a 
sepultura do valoroso Heitor promoveu homenagens e solenidades em memória de suas proezas ${ }^{20}$. A narrativa de André Thevet promoveu, sobretudo, um curioso debate com a tradição, seja clássica, seja contemporânea, e reuniu testemunhos escritos, visuais e materiais capazes de fomentar o avanço do conhecimento. Não procurou contestar todo o conhecimento clássico, ao contrário, por vezes reabilitou-o. Como bem salientou no prefácio, ele pretendia promover o contentamento e o proveito das pessoas estudiosas e ainda enriquecer as boas letras. Nesse sentido, os objetivos do frei pouco se coadunavam com a produção escrita dos primeiros conquistadores que percorreram o Brasil no quinhentos. Por certo, os desbravadores, particularmente os portugueses, procuravam reunir informações geográficas e conhecimento sobre os povos com a intenção de viabilizar a manutenção das conquistas. O diálogo com os eruditos estava certamente em segundo plano ${ }^{21}$. Os portugueses, ao percorrer o litoral americano, procuravam mapear terras e povos para dispor de mais conquistas. O saber, portanto, deveria agir em favor da colonização e não se endereçava aos gabinetes e circuitos eruditos europeus. $O$ frei também não se ateve às estratégias próprias da catequese e nem tornou a sua narrativa um libelo em favor da cristianização das novas terras, como fariam, mais tarde, os capuchinhos no Maranhão ${ }^{22}$.

Entre os séculos XVI e XVII, as informações produzidas sobre as terras brasílicas percorriam os caminhos em direção a Lisboa ou para outros centros localizados muito além dos Pirineus, em cidades como Paris, Amsterdam e Roma. Depois de transcritas, as notícias eram publicadas ou armazenadas pelos reinos rivais ou pela Igreja. Finalizava assim o percurso de inventários indispensáveis ao aumento dos impérios ou da fé católica. A luta por mercados e a expansão da cristandade produziram registros que hoje se tornaram fundamentais para conhecer o Brasil entre os séculos XVI e XVII. Inúmeros testemunhos percorreram o Brasil e deixaram escritas suas impressões. Além dos lusitanos, os franceses e os holandeses também pretendiam comercializar produtos e, por vezes, 
estabelecer colônias em regiões sob o domínio português. Os relatos de viagem descreviam as rotas marítimas, os índios e os recursos naturais capazes de prover o sustento de colonos e conquistadores futuros. Mesmo incipientes, os vassalos do rei de França, particularmente os religiosos, escreviam sobre as terras americanas para incentivar o apoio do monarca à catequese dos ameríndios e à defesa armada dos novos empreendimentos coloniais.

Sem o mesmo impacto dos livros de Thevet, vieram a lume os escritos do capuchinho Claude d'Abbeville que viajou ao Brasil como missionário e participou da França Equinocial. A missão pretendia consolidar a conquista francesa e despertar os ameríndios do "profundo sono do pecado", ressuscitando-os para "vida da graça". Para frei d'Abbeville, os índios permaneciam afastados da cristandade e submersos na escuridão. Mas eram, porém, almas predestinadas ao reino da Igreja. Cabia ao "magnífico reino entre os reinos da terra", a França, libertar das trevas essas "almas de canibais e antropófagos" ${ }^{23}$. Com esse discurso, o capuchinho buscava legitimar a conquista francesa e cristianizar os povos do Maranhão. O frei Yves d'Evreux também se preocupou com a conversão das almas, convencido de que o Criador concebera o espírito humano com a capacidade de reconhecer a verdadeira fé. Mas somente após a conversão poderia esse espírito desenvolver as sementes plantadas pelo Todo Poderoso. Em contrapartida, enquanto permanecesse sob o jugo tirânico do Demônio, ficaria imerso na escuridão das trevas, padecendo de fome e necessidade. Antes de Thevet, preocuparam-se com a conversão das almas americanas os religiosos espanhóis e portugueses. Por meio das controvérsias promovidas por Bartolomé de Las Casas e divulgação de cartas jesuíticas provenientes das conquistas portuguesas, publicadas entre 1549 e 1551, o tema da conversão era de amplo conhecimento ${ }^{24}$. Nem por isso sensibilizaram o frei de Angoulème para a salvação dos ameríndios.

Enfim, a comparação com os religiosos ibéricos e com os capuchinhos da França Equinocial ${ }^{25}$ permite constatar a 
"singularidade" dos escritos do frei André Thevet. Em parte, tratava-se da primeira grande narrativa sobre a natureza e os povos sul-americanos, em um momento em que os franceses ainda lançavam incipientes investidas conquistadoras. A fragilidade do empreendimento colonial pode, de todo modo, explicar o interesse do frei em dialogar com eruditos ao invés de promover inventários destinados a sustentar as conquistas. Ao longo da narrativa sobre a viagem à França Antártica, ficam evidentes os diálogos travados com a tradição clássica. $O$ frei prestava ainda homenagem a seus superiores que viabilizaram as viagens e o privilégio de editar as obras. Cosmographie de Levant ${ }^{26}$, de 1554, foi dedicada ao monsenhor François, conde de la Rochefoucaud, e Les Singularitez de la France Antarctique, de 1557, ao monsenhor reverendíssimo cardeal de Sens. Depois da breve permanência na América, presenteou o Senhor de Troistieux com o manto tupinambá, o Senhor de Nicolas de Nicolai, geógrafo do rei, com um maracá e o rei Henrique com um chapéu com plumas de tucano. Assim, torna-se evidente que as peças americanas serviam como dom para o frei obter privilégios e, talvez, o cargo de cosmógrafo do rei. Logo depois da publicação da aventura americana, por volta de 1560, ele tornou-se o primeiro cosmógrafo da França. Entrou, segundo Frank Lestringant ${ }^{27}$, para clientela de Catarina de Médicis e serviu a Henrique II e a seus três filhos Francisco II, Carlos IX e Henrique III. Nesse tempo, ele ainda atuava como guardador do gabinete de curiosidade do rei. Sua adesão à Santa Liga ultracatólica tornou inviável sua permanência como cosmógrafo de Henrique IV e criou várias inimizades nos circuitos eruditos. Esses indícios, portanto, levam-me a acreditar que os escritos de Thevet estavam mais voltados aos poderosos de França do que destinados a viabilizar a colonização na América.

Apesar dos cuidados, Thevet teve de enfrentar o descrédito lançado sobre as suas obras por parte dos contemporâneos. Nesse sentido, Jean de Lery ${ }^{28}$, que também esteve no Rio de Janeiro, considerou que Les Singularitez de la France Antarctique e La Cosmographie Universalle (1575) de Thevet estavam prenhes de mentiras, razão para ele contestá-las e 
escrever a sua própria versão dos fatos. O filósofo Michel de Montaigne duvidava da fidelidade da própria cosmografia, enquanto a erudição de Thevet seria questionada por Mathurin Héret e François Belleforest, dois de seus maiores colaboradores na produção de suas primeiras obras ${ }^{29}$. Sua aliança inicial com os reformados e a traição desses princípios ao se vincular à liga católica contribuíram para que seus testemunhos caíssem em descrédito quase geral. Enfim, seus escritos, imagens, e até mesmo os artefatos e as doações não foram capazes de evitar que suas experiências e comprovações fossem desacreditadas por seus contemporâneos.

RAMINELLI, Ronald José. Writings, Images and Artifacts: Or Thevet's Voyage to the French Antarctic. História, v.27, n.1, p. 195-212, 2008.

Abstract: Through his writings, images and artifacts, Father Andre Thevet, the King of France's cosmographer, recreated the plants, animals, peoples and geography of the New World. The graphic resources and collections permitted the circulation of information, proved their written registers, and certainly made this data available to the King, nobles and other curious people. The advances of the printing press made it possible to spread the knowledge of the distant world, with the certainty that it reached more and more people, a much larger public, while the collections themselves remained restricted to the scope of the aristocrats. The intention thus is to investigate "American elements" chosen and gathered by Thevet to confirm his trip and make it evident or represented by his contemporaries.

Keywords: French Antarctic; French Colonization; Andre Thevet. 


\section{NOTAS}

1 F. André Thevet. Les singularitez de la France antarctique. Paris: Chez les Heritiers de Maurice de la Porte, 1558.

${ }^{2}$ Vasco Mariz \& Lucien Provençal. Villegagnon e a França Antártica. Rio de Janeiro: Nova Fronteira, 2005. p. 83-103.

${ }^{3}$ Idem. Ver: Privilege, Epistre e Preface.

4 Sobre sistema de patronagem ver: Mario Biagioli. Galileu Courtier; the practice of science in the culture of absolutism. Chicago: Chicago Um. Press, 1994. p. 13-101.; Norbert Elias. A sociedade de corte. (trad.). Lisboa: Estampa, 1995.

${ }^{5}$ F. André Thevet... p. 47 v. "Et qu'aint foit, il pourra etre veu par une robe ainsi faite, de la quelle i'ay fait present à Monsieur de Troistieux gentil-homme de la maison de monseigneur le Reverendissime Cardinal de Sens, \& garde de seaux de France, homme, dit-ie, amateur de toutes singularitez, \& de toutes personnes verteueses." A tradução empregada ao longo do texto encontra-se no livro: André Thevet. As singularidades da França Antártica. Tradução de Eugênio Amado. Belo Horizonte: Ed. Itatiaia, 1978. Para o trecho acima ver p. 90.

6 Sobre gabinete de curiosidades ver: Peter Mason. Infelicities, representations of the exotic. Baltimore: The John Hopkins University Press, 1998.; Paula Findlen. Possessing nature. Los Angeles: University of California Press, 1996.; Krzysztof Pomian. Collectionneurs, amateurs et curieux. Paris: Gallimard, 1987.; Lorraine Daston and Katharine Park. Wonders and the order of nature. New York: Zone Books, 1998.; Christian F. Fest. The collecting of American Indian artifacts in Europe, 1493-1750 in: Karen O. Kupperman (ed.) American in European consciousness - 1493-1750. London: North Caroline Press University, 1995.; Adalgisa Lugli. Naturalia et Marabilia; les cabinets de curiosité en Europe. (trad.) Paris: Adam Buro, 1998.; Detlef Heikamp. Mexico and the Medici. Firenze: Editrice Edam, 1972.

${ }^{7}$ F. André Thevet... p. $105 \mathrm{v}$

${ }^{8}$ Idem. p. 91. “... aux quels les oreilles pédent jusques aux talons: les autres avec um oreil au front, qu'ils apellent Arismafes: les autres sans teste; les autres n'ayans qu'un pié, mais de telle longueur qu'ils s'en peuvent ombrager contre l 'ardeur du soleil..." Tradução Thevet....p. 83. ${ }^{9}$ Idem. p.p. $42 \mathrm{v}-43$.

10 Sobre a tradição clássica ver: Paul Kristeller. Tradição clássica e pensamento do Renascimento. (trad.) Lisboa: Ed. 70. , 1995.; Paolo Rossi. A Ciência e Filosofia dos Modernos. (trad.) São Paulo: Ed. Unesp, 
1992.; José Antonio Maravall. Antiguos y Modernos. Madrid: Alianza Editorial, 1983.; Eugenio Garin.L' umanesimo italiano; Filosofia e vita civile nel Rinascimento. (trad.) Roma-Bari: Editori Laterza, 2000.; Agnes Heller. O homem do Renascimento. (trad.) Lisboa: Editorial presença, 1982.

${ }^{11}$ F. André Thevet... p. 51.

${ }^{12}$ Idem. p. 36.

${ }^{13}$ Idem p. 39v.

14 Idem p. 48. "Entre lesquelles i'en descriray un cest endroit, mostrueux, pour un poisson d'eau douce, autant qu'il est possible de voir. Ce possoin est de grandeur \& grosseur un peu moindre que notre haréc, armé de teste en queuë, comme un petit animant terrestre nomé Tatou, la teste sans comparaison plus grosse que le corps, ayant trois os dedans l'eschine, bon à manger, pour le moins en mangent des Sauvages, \& le nomment en leur langue, Tamouhata". Tradução ver p. 91

${ }^{15}$ Idem. p. 50.

${ }^{16}$ Idem p. 99v-100. “... de la grãdeur d'un bien grãd guenon d'Afrique, son ventre est fort avalé contre terre. Elle à la teste presque semblable à celle d'un enfant, \& la face semblablement, comme pouvez voir par la presente figure retirée du naturel. Estãt prise elle fait des souspirs comme un enfant afligé de douleur. Sa peau est cendrée \& veluë comme celles d'un petit ours. Elle ne porte sinõ trois ongles aux pieds longs de quatre doigts, faits en mode de grosses arestes de carpe, avec lesquelles elle grimpe aux arbres, ou elle demeure plus qu'en terre. Sa queuë est longue de trois doigts, ayant bien que cette beste n'a jamais esté veuë manger d'homme vivant, encores que les Sauvages en ayant tenu longue espace de temps, pour voir si elle mangeroit..."Tradução ver p. 169.

${ }^{17}$ Idem p. $73 \mathrm{v}$.

${ }^{18}$ Idem p. 73.

${ }^{19}$ Idem p. 82v.

${ }^{20}$ Idem p. 81v-82v.

${ }^{21}$ Sobre o pragmatismo português ver: Sérgio Buarque de Holanda. Visão do Paraíso. São Paulo: Companhia Editora Nacional, 1985;

Caminhos e Fronteiras. São Paulo: Companhia das Letras, 1994; J.S. da Silva Dias. Os descobrimentos e a problemática cultural do século XVI. Lisboa: Editorial Presença, 1982.; Laura de Mello e Souza. O Diabo e a Terra de Santa Cruz. São Paulo: Companhia das Letras, 1986. 
${ }^{22}$ Sobre os capuchinhos do Maranhão ver:; Yves d'Evreux. Voyage au Nord du Brésil fait em 1613 et 1614.Presentation et notes d'Hélène Clastres. Paris: Payot, 1985.

${ }^{23}$ Claude d'Abbeville. Histoire de la mission des Pères Capucins en l'isle de Maragnan et terres circonvoisines. Paris, 1614. Ver Préface.

${ }^{24}$ Sobre debates quinhentista em torno da conversão ver: Cartas dos jesuítas do Oriente e do Brasil 1549-1551. Edição facsimilada. Lisboa: Biblioteca Nacional, 1993.; Ronald Raminelli. Imagens da Colonização.Rio de Janeiro/São Paulo: Jorge Zahar/ Fapesp/Edusp, 1996.; Anthony Padgen. The fall of natural man. Cambridge: Cambridge University Press, 1982. Lewis Hanke. The Spanish struggle for justice in the conquest of America. Boston: Brown \& co., 1965.

${ }^{25}$ Andrea Daher. Les singularités de la France équinoxiale: histoire de la mission des pères capucins au Brésil.Paris: H. Champion, 2002.

${ }^{26}$ F. André Thevet. Cosmographie de Levant. (1554) Genève: Droz, 1985.

${ }^{27}$ Frank Lestringant. Le Huguenot et le Sauvage. Paris: Aux Amateurs de Livres, 1990. p. 39-43.

28 Jean de Léry. Histoire d'un voyage faict en la Terre du Brésil.(1578) Texte établi, présenté et annoté par Frank Lestringant. Paris: Livre de Poche, 1994. p. 105-6.

${ }^{29}$ Frank Lestringant. L'atelier du cosmographe ou l'image du monde à la Renaisssance. Paris: Albin Michel, 1991. p. 27-55.

Artigo recebido em 03/2008. Aprovado em 07/2008. 